\title{
The semantic resonance as a way of representation of the national identity's conceptosphere in Oksana Pakhlovska's essays
}

\author{
K. Petriv \\ Taras Shevchenko National University of Kyiv, Kyiv, Ukraine \\ Corresponding author. E-mail: pettriv.xr@gmail.com \\ Paper received 27.03.18; Accepted for publication 01.04.18.
}

https://doi.org/10.31174/SEND-Ph2018-160VI47-12

Abstract. The paper analyzes the phenomenon of semantic resonance as a way of influence on the recipient in Oksana Pakhlovska's texts. It deals with the linguistic and extralinguistic factors of its realization and complex multi-sensor nature, which provokes emergence of emotional images in the addressee's mind. In the sociopolitical discourse the influence on recipients isn't conducted only by linguistic means, but also by non-linguistic ways. The recipient usually perceives information mentally, visually, acoustically, graphically etc.

Keywords: recipient, concept, semantic resonance, suggestion, verbalization.

Introduction. The influential effect of the resonance phenomena in different situations has been known for a long period. At the same time, the typology of resonance effects and methods of their construction in the text discourse is relatively a new topic of the scientific research. The linguistic investigation of semantic resonance was actualized using the practice of neurolinguistic programming, political propaganda, advertisement, didactic needs etc. The redefinition of the interaction between emotional and rational constituents in the person's consciousness, the necessity of pragmatic creation of semantic or emotional dominants of informational perception, depending on the specifics of solving communicative tasks contributed to studying resonance in the theoretical and practical contexts of verbal influence, especially - verbal-suggestive.

The research aims to define the phenomena of semantic resonance in Oksana Pakhlovska's social and political essays and to analyze its influence on the recipients. The following tasks should be solved to reach the setting aim: to analyze functions of verbal suggestion in the author's publications; to define and to separate lingual and extralingual factors of influence; to observe its functioning in the publicistic discourse (on the material of Oksana Pakhlovska's works). The function of influence in publicistic texts is one of the main, however, suggestive mechanisms of its realizations, especially semantic resonance, are still unclear, that make the topic of our research of high priority.

Methods and material. O. Pakhlovska's essays served as research material. Methods of semantic and component analysis were chosen as the leading here.

Overview of publications related to the theme. Foreign scientists David Miall, Keith Oatley and Ukrainian scientists O. Vorobjova, O.Klymentova, M. Skab, N.Slukhay, O. Snytko, Russian linguist Belyanin etc. applied to different approaches of psychological and linguistic effects, suggestion and semantic resonance concerning its communicative specifics.

The significant influence of emotions on the experience of world is admitted by Keith Oatley in his work "Psychology of emotions", disproving the primary role of knowledge in the creation of mind [13, p.3]. The ways of completing emotional resonance in the text are also investigated by $\mathrm{O}$. Vorobjova and among them she mentions the using of verbal imagery and phonosemantics, syntactic, architectonic and compositional rhythms, configurations of thematically consolidated vocabulary, associative series etc [10, p. 74].

O. Klymentova identifies such functions of verbal suggestion: fixation, codification, translation, accumulation and transformation of actual senses. Each of them is objectified due to different sensory channels: visual, auditory, kinesthetic etc [4; 2, p.109]. Information that is transmitted with taking into account the specifics of its representation through several channels, is much more valid comparing to other stimulus, thus it latently forms effects of semantic resonance. On the one hand, this resonances are motivated by the specifics of categorization of information, on the other hand - can be pragmatically imposed [4, p. 109]. However, the text organization of these effects has such individual stylistic specifics that is still unclear.

Results of the investigation and their discussion. Oksana Pakhlovska's social and political essays are complicated texts according to different parameters. "In the semantics of complicated texts, - writes V.Belyanin, - the desire of "the middle person" to understand something unusual, difficult, unknown, is the leading one" [1].

O. Pakhlovska's texts are mainly analytical, at the same time their perception includes the synthesis of senses, symbolical summary that becomes the result of semantic resonances.

Many articles have the word-symbol in the heading, which is interpreted in the text with the help of other equivalent symbols. For instance, in the essay "In meanders of European amnesia: between AUSTRIA FELIX and PAX MOSCOVITA" ("В меандрах європейської амнезії: між AUSTRIA FELIX i PAX MOSCOVITA") the word amnesia is a symbol that is resonated several times in the text. Although this word itself is used in the article only four times, but some other words-symbols every time force the recipient's thinking to appeal to the heading. Thus, for instance, precedential name Dunaj which dominates in the article preserves in the native speaker's consciousness the memory about emotional experience and increases the influence of the symbol. Dunaj in Ukrainian culture is the symbol of border that divides two worlds. In folklore crossing the river meant the transition from earthly existence to unearthly one.

Today's Dunaj as the water border divides the world into two parts: on the one side there is Ukraine that is politically and economically unstable state, on another side, European Union countries with the high level of industrial development, democracy and freedom. Therefore, the sym- 
bolism of Dunaj resonates with the symbol of amnesia. O. Pakhlovska describes this river in such way: Ïxamu за Дунай» означало попрощуатися назавжди. Не повернутися, загинути. Силует вериника на коні. Жіночі заломлені руки [6, p. 190].

Images, that induce emotional resonance that not only decodes the thought but also consolidates attitude to it, can be absolutely different and can be formed by different methods [10, p. 76].

The associative link emerges in the process of personal and genetic experience. In the above-mentioned essay the symbolic meaning of the river Dunaj is entranched in genetic, subconscious recepient's memory. To cause the surplus of emotional impressions, O. Pakhlovska appeals to Dunaj again, imposing on the recipient those feelings that seem to be accidental, but in fact are united by the common emotionality: Для України ияі «Дунайські ворота» були мов містичне дзеркало між реальним світом $i$ потойбіччям [6, с. 190]. As in the previous example Pakhlovska goes on injection of negative emotions, the fear of close death, forgetting, hopelessness and troubling. The conceptual metaphor of amnesia that is straight-through in the text, due to semantic resonance makes the net of conceptual integration, one of the components of which is the mental space of the river Dunaj: Дунай $і$ сьогодні, як $у$ давнину, пов'язує Захід $i$ Схід, а отже, й мозайчну багатоманітність культур, щу постали з синтезу $і$ протистояння західного та східного християнства, Риму ü Константинополя [6, p. 190]. The idea of dividing world into civilization and barbaric by Dunaj is kept in the whole text. By the way, earlier Dunaj symbolized the impenetrable border, but now, in the author's opinion, - vice versa: the border is not steady and some historical moments can flow one inside the another.

While perceiving the text there is the phased relocation of the recipient's attention from one, relatively completed part, to another: the recipient tries to "link" different elements of the text into the whole part [1, p.27].

The sense in the text is supported not only by a word, image or symbol, but acoustically, with the help of smell, ritual action etc. Therefore, the author appeals to the acoustic means, remending the recipient about the Johann Strauss's II waltz “An der schönen blauen Donau”: Cлinyча блакить музики, в якій тонула у захваті Свропа ХІХ століття. Дунай неминаючої краси, Дунай рятівного забуття і сьогодні огортає Європу і світ, долинаючи все з тієї самої Віденської філармонії щороку в Новорічну ніч... [6, p. 197].The specific frame of the article is created by another melody - the melody of song “Ой Дунаю, Дунаю, чому смутен течеш?", because by these words the author starts the article and by these lines she finishes.

The sense of amnestic state of Ukraine is duplicated by another sound of the Ukrainian song "Їхав козак за Дунай...", which as the author mentions, appealing to the European space, becomes especially popular in Europe: $Y$ 1815 роиі шість варіацій на ичю тему напише Карл Марія Вебер, засновник німецької романтичної опери, про якого згадуватиме Шевченко у свойх повістях та «Щоденнику». Наступного, 1816 року, десять варіацій для фортеп'яно створить Бетховен [6, p. 190].

The translation of senses, as we observe, occurs not only due to the verbal influence, but with the help of sound images which are latently available in the text, framing it and coding the verbally-accentuated senses in the range of metaphors.

By means of visual images there is another mental space created - the space of disappearing memory, hopelessness of history and disappearance of time that is semantically relevant to the space of amnesia, represented in the heading. Such images are “два чорні лебеді / календарного білого моря" ("two black swans of the calendar white sea"), that is the allusion to the Lina Kostenko's poem " 22 ". Using the stylistic mean of interrogation that has the suggested answer, appeals again to the river Dunaj: Чому иі лебеді пливуть з Дунаю? Чому це перетікання зловісних дат, які символізують безвихідність Iсторії, відбувається саме над тихим плесом lстра-Danuvius'al [6, p. 197].

The author answers the stated interrogation herself, reminding again that the river represents mythological (thus cyclic) time, and it means that the recurrence of historical dates is inevitable: Як усі великі ріки, Дунай є Рікою Часу. Але Дунай - ие насамперед Ріка Європейського Yacy [6, p. 197].

The semantic resonance, objectified by the means of acoustic images, is prevalent in Pakhlovska's essays, since sound effects are the most emotionally significant. As David Miall mentions, emotions are the basis of semantic perception. Hence, the interpretation of the text may be absolutely different in relation to the core emotions of the recipient [11]. However, the emotional part forms the core of concepts, thus appeals to emotions through different sensor channels makes it possible to perceive information.

Emotions are important both in communication and in cognition, but in many situations emotions emerge only after mental process that is connected with the nature of our experience, the wide spectrum of stimulus and situations that cause emotions by the means of associative influence. O. Klymentova emphasizes that emotions are directly connected with interpretative verbal processes. Because the access to verbalization of emotions can be controlled by suggester (and even be the object of manipulation), the emotive correlation takes the meaning of active mechanism of the verbal effect [3, p. 84].

The verbalizators of auditory features takes the significant place in Pakhlovska's essays. The auditory perception often can bear associations with time and place. Therefore, in several articles the concept of Ukrainian entry to the European Union is sometimes verbalized through the piece of music "Ode to Joy" written by Beethoven: Ось, власне, мініатюрний сочіокультурний портрет польського суспільства, який пояснює, чому в ніч на 1 травня на площуах польських міст звучала “Ода радості” Бетховена, а в Украӥні кілька днів по тому вибухали снаряди в мелітопольських степах [6, p. 244]. The antithesis of Ukrainian and Polish locus is often represented through the acoustic verbalisator "Ode of Joy". Thus, for instance, in the article "Poland and Ukraine on May 1, 2004: Beethoven's "Ode of Joy" on the edge of new reservation" («Польща і Україна 1 травня 2004 року: «Ода радості» Бетховена на кордоні нової резервації») using the semantic resonance the author creates the semantic resonance of the dichotomy, mentioned in the heading, that is duplicated by the visual resonance: Пояснює, чому польська молодь розгойдувала в нічному периотравне- 
вому небі різнобарвні прапори свропейських міст, а на вулииях Києва на ранок подекуди пенсіонери витягали з ідеологічного нафталіну зім'яті прапори все того самого незмінно червоного кольору, так наче ще недостатньо крові було пролито під стягами диктатури [6, p. 245].Comparing and contrasting the colour scheme of European cities' flags and the red colour as the echo of soviet power, the author continues to call the associative range in the recipient's consciousness: Poland - "Ode of Joy" - diversity; Ukraine - shells - red colour (that is, furthermore, the colour of blood and death). Such opposition is the basis of the article that is shown from the beginning till the end, not only leads to recipient's understanding but also escalating fear about loosing by Ukrainians their state and identity: Це означає, щзо Польщза системно й послідовно працює над тим, щзоб БУТИ. А Украӥна системно й послідовно готує себе до політичного $i$ культурного НЕІСНУВАННЯ [6, p. 248]. Counts show that the word "border" ("кордон") itself is used in the article 29 times and it detects verbal resonance. Furthermore, several times the author uses anaphor - the strong position of the text regarding the recipient's balance of attention. Such compositional device also serves the phenomenon of semantic resonance: Цей кордон проліг тому, щзо Польщза зробила свій вибір. А Украӥна - ні. Цей кордон проліг тому, що Польщза поважає себе $i$ вміє змусити інших поважати себе. А Украӥна - ні. Цей кордон проліг тому, щзо Польща більше ніколи не дозволить Росї̈ нищити свій народ, свою культуру, свою державність. А Украӥна - так. Цей кордон проліг тому, щз Польщза готова заплатити високу ціну важкою працею $і$ тимчасовими жертвами,- - за свою рівноправну з іншими народами присутність в Свропі [6, p. 247-248].

The semantic resonance is actively used on the basis of acoustic echo in the article "Ave, Mater Dolorosa". The article's heading appeals to the Roman Catholic anhem "Stabat Mater Dolorosa", whose author is considered to be the Italian poet of XIII century Jacopone da Todi. The text tells about Virgin Mary's sufferings at the moment of JesusChrist's crucifixion. At the same time this image in Oksana Pakhlovska's essays plays the role of activator of ethnically marked images because of allusion to Ukrainian literature where the image of Ukraine arises. There occurs the resonant interaction of texts from different times and cultures that is objectified on the level of concepts. The concept "GRIEF" is verbalized through mentioning Taras Shevchenko's "Neofity" and arises associations with the mother, who saw the tortured son's body having been dropped into Tybr, and appeal to Pavlo Tychyna's "Skorbna Maty" ("Lady of Sorrows")is accompanied by quotations that involve not only associations but also repeated consolidation of the image Ukraine, which the author tried to decode in test using the concept "GRIEF" by stringing allusions.

At the end of the text we observe the acoustic image that is leading in many Pakhlovska's articles - Beethoven's "Ode of Joy", however in this case target images are born in the recipient's mind by using antithesis: Тому поки щзо наш гімн Свропи сьогодні - ие “Stabat Mater". Скорбна Мати біля хреста<...>. Ще довга дорога до “Оди радості” Бетховена. I до права ї̈ чути зі щзасливим усміхом і вільною душею [7]. The opposition of Ukrainian grief and European happiness is a leading idea, objectified by O.Pakhlovska. The acoustic image that arises in text is the marker of ethnic and religious world outlook, since the anthem "Stabat Mater" is the core of the conceptual sphere of identity for Catholics; The anthem "Ode of Joy" by Beethoven is conceptually important for Europeans.

Te word "ave" means "hail", it is the word-stimulus, creates the associative link with phrase "Ave, Maria", but the author immediately denies such reader's reflexion: Щоб ие сталося $і$ справді, хай через багато років, сьогодні маємо сказати AVE матерям циих хлопців. I не радісне «Аве, Марія», - символ Благовіщення. Це Аvе, Mater Dolorosa. Аве, Скорбна Мати. Жінки, які народили циих хлопців. Які їх любили. Які народжували їм діток- або ци не встигли [7].The anaphoric device demonstrates the phenomenon of phonetic resonance that verbalizes the development of concept mother or Mater Dolorosa.

Appeal to acoustic images is often realized and supported with the aim of actualization of senses connected with Ukraine. In the article "Hoo, Banana Republic" ("Гей, Республіка Банана") the heading calls for associations with underdeveloped, forgotten, small countries of so called "Third world"/ the recipient from the first lines guesses that it deals with Ukraine: Могутньою хвилею епічної музики здіймаються заключні акорди “Реве та стогне...” - $і$ опадають у каструлю, де смачно киплять спагетті “Barilla” [6, p. 113]. O. Pakhlovska introduces for recipients Italian cultural space, but the acoustic image - song "Реве та стогне" - appeals to Ukraine. Later the recipient understands that the article actualizes the image of Ukraine as unjustly forgotten part of Europe, as all Ukrainian merit were inevitably attributed to Russia. Hence, Pakhlovska raises the rhetoric interrogation: $I$ де ж ми $\epsilon$ ? I чи ми ж $\epsilon$ [6, p.113]?

Conclusions. In publicistic discourse, within which we have analyzed O.Pakhlovska's text, the author's influence on the recipient is formed not only by lingual but also by paralingual means. The recipient perceives text simultaneously by several means: graphically, mentally, visually, acoustically, kinesthetically etc. The analysis of O. Pakhlovska's texts has demonstrated mainly acoustic influence on the recipient, as the validity of some ideas is created and supported usually by reinforcement of semantic blocks by acoustic images. However, those cases when the concept resonates by several means at the same time acoustically, visually, kinesthetically, - are significant in Pakhlovska's texts. In our opinion, such resonance aims at creation and accumulation in recipient's mind appropriate (mainly - emotional) images and to encode the image for the author to decode it in such a way, as the author needs. In spite of difficulty and high intellectuality of Pakhlovska's texts such images are not very numerous, because of concreteness and categoricalness that are peculiar to O. Pakhlovska's style, but those available are deep and symbolical. Meanwhile, the using of potential of the verbal influence (especially, latent) is insufficient and unjustified. Probably, it is one of the reason why O. Pakhlovska's articles doesn't usually meet the expectations of social reflexion on the potentially powerful author's ideas. 


\section{REFERENCES}

1. Belianin V. Psychological and linguistic aspects of the literary text / V.Belianin. - M.:MSU, 1988. - 120 p.

2. Klymentova O. The semantic resonance in the sacral texts / O. Klymentova // The system and structure of Eat Slavic languages. - 2011. - Issue 3. - P. 108-114.

3. Klymentova O. Verbal suggestion and emotions (based on Ukrainian prayers). - K.: Karbon LTD, 2012. - 320 p.

4. Klymentova O. Verbal suggestion as a system of functions / O. Klymentova // The system and structure of Eat Slavic languages: dedicated to the $175^{\text {th }}$ anniversary of M. Drahomanov NPU. Collection of scientific articles. - K. Osvita Ukrainy, 2010. - P. 149-157.

5. Klymentova O. Verbal suggestion of sacral texts (based on Ukrainian prayers): dissertation abstract: 10.02.01. - K., 2013. - P. 3, 32 .

6. Pakhlovska O. Ave, Europa! / O. Pakhlovska. - K.: Pulsary, 2008. $-656 \mathrm{p}$.

7. Pakhlovska O. Ave, Mater Dolorosa [Electronic source]. Access mode: https://day.kyiv.ua/uk/article/nb/ave-materdolorosa
8. Pakhlovska O. The space of Sophia [Electronic source]. - Access mode: https://day.kyiv.ua/uk/article/istoriya-i-ya/prostirsofiyi-2

9. Slukhai N. The verbalization of sensor prototypes in poetic works of Taras Shevchenko: colour and sound / N. Slukhai // Shevchenkoznavchi studiji. - 2011. - Issue 14. - P. 236-247.

10. Vorobjova $\mathrm{O}$. The idea of resonance in the linguistic investigations / O. Vorobjova // Language. Person. World. Dedicated to the $70^{\text {th }}$ anniversary of professor M. Kocherhan. $-\mathrm{K} . \mathrm{KSLU}$, 2006. - P. 72-86.

11. David S. Miall, Don Kuiken. Beyond text theory. Understanding literary response. / David S. Miall, Don Kuiken // Discourse Processes. - 1994. - 17. - P.337-352. - Access mode: http://cogprints.org/724/1/BEYOND_t.htm

12. Iconicity. $\quad-\quad$ Access http://iconicity.ch/en/conferences/index.php?subaction=showfu $11 \&$ id $=1196955621$ \&archive $=$ \&start_from $=\& u c a t=3 \&$

13. Keith Oatley. Best Laid Schemes: The Psychology of Emotions. - Cambridge University Press, 1995. - 525 p.

Семантический резонанс как способ репрезентации концептосферы национальной идентичности в публицистических текстах Оксаны Пахлевской

Х. В. Петрив

Аннотация. В статье проанализировано явление семантического резонанса как способа влияния на реципиента в текстах Оксаны Пахлевской. Исследовано лингвальные и экстралингвальные факторы его реализации, а также комплексный полисенсорный характер, который провоцирует порождение эмоциональных образов в сознании адресата. В социополитическом дискурсе влияние на реципиента может быть ментальным, визуальным, графическим ил аудиальным.

Ключевые слова: рециипиент, конщепт, семантический резонанс, сугzестия, вербализачия. 